ks. Marek Jagodziński

Katolicki Uniwersytet Lubelski Jana Pawła II

DOI: $10.15290 /$ std.2016.02.04

\title{
KOMUNIJNA WIZJA SAKRAMENTU MAŁŻEŃSTWA
}

\section{COMMUNIONAL VISION OF THE SACRAMENT OF MARRIAGE}

Contemporary theology emphasizes the personalistic dimension of sacraments as visible and tangible signs of closeness and presence of God, signs and tools of communication and communion. This also applies to the sacrament of marriage. Based on the Bible and the teachings of the Church can easily be shown that the sacrament of marriage is communicative activity in the service of communion. In this way this sacrament becomes the sacrament of conjugal and familial service of communion.

Key words: sacrament, personal sacramentology, person, communication, communion, marriage, family.

Niezwykle dynamiczna debata, która rozgorzała w świecie w związku z pracami XIV Zwyczajnego Zgromadzenia Ogólnego Synodu Biskupów na temat powołania i misji rodziny w Kościele i świecie współczesnym ${ }^{1}$, ukazała ogromne

Niezwykle wysoką temperaturę miała ta dyskusja w Niemczech, co ukazuje przykładowo przegląd publikacji nawet w jednym tylko czasopiśmie „Herder Korrespondenz”: P. M. Zulehner, Differenzierung ist nötig. Was Katholiken über die Ehe denken?, 3 (2014), s. 129-134; S. Demel, (K)ein Widerspruch? Unauflöslichkeit der Ehe und Zulassung zu einer Zweitehe, 6 (2014), s. 303-307; U. F. Schmälzle, Es geht um Heilung. Für eine alternative Pastoral zum Umgang mit wiederverheirateten Geschiedenen, 7 (2014), s. 348-353; J. G. Gerhartz, Wirklich unauflöslich? Die Ehe in Lehre und Praxis der katholischen Kirche, 8 (2014), s. 389-393; E. Schockenhoff, Die zwei Seiten eines Texte. Die Wortmeldung des emeritierenden Papstes zur Debatte um wiederverheiratete Geschiedene, 12 (2014), s. 605 609; J. Ratzinger/Benedikt XVI, „Zur Frage nach der Unauflöslichkeit der Ehe”. Die beiden Textversionen von Joseph Ratzinger/Benedikt XVI, 12 (2014), s. 609-612;. J. Splett, Ehe als 
zapotrzebowanie na pogłębioną teologię sakramentu małżeństwa. Sprzyja jej rozwój współczesnej sakramentologii, w centrum której znajduje się nie tyle ontologiczne działanie sakramentów, co raczej sam akt ich pośredniczenia ${ }^{2}$. W takim świetle na sakramenty można patrzeć jako na widoczne i uchwytne znaki prawdziwej bliskości i obecności Boga, znaki i narzędzia komunikacji i komunii, służące budowaniu komunikacji i komunii z Bogiem i ludźmi³ Personalistyczne rozumienie sakramentów podkreśla, że „sakrament jest przypadkiem realnej, aktualnej i historycznej komunikacji Osób Bożych z osobą człowieka”, jest objawioną trynitarną ekonomią Zbawienia, urzeczywistnianą „na sposób uobecnienia liturgicznego w siedmiu swoich znakach ewangelicznych o charakterze żywej komunii między Bogiem a człowiekiem" ${ }^{4}$. Sakramentalne pośrednictwo dokonuje się przy pomocy Kościoła, który w mocy Ducha Jezusa Chrystusa przekazuje w znaku wcieloną obecność Bożego Zbawienia 5 .

Katechizm Kościoła Katolickiego dzieli siedem sakramentów na trzy grupy: „sakramenty wtajemniczenia chrześcijańskiego”, „sakramenty uzdrowienia” i „sakramenty w służbie komunii”. Nie jest to oczywiście jedyny możliwy porządek, ale pozwala dostrzec, że sakramenty tworzą pewną strukturę, w której

Bund. Zur Diskussion um den Status Wiederverheirateten, 3 (2015), s. 144-149; J. Sautermeister, Zum Prinzip der Gradualität im Kontext der Familiensynode. Das Prozesschafte in der Lebensführung, 5 (2015), s. 229-233; P. Neuner, Können wiederverheiratete Geschiedene zum Kommunionempfang zugelassen werden? Nicht immer schwere Sünde, 6 (2015), s. 299-302; V. Resing, Interview mit Bischof Franz-Josef Bode über die Familiensynode. „Die Fixierung auf das Sexuelle überwinden", 8 (2015), s. 402-204; M. Werlen, Die katholische Kirche und die Herausforderung des Zeitgeistes. Angesichts der Traditionen die Tradition nicht vergessen, 9 (2015), s. 463-466; P. Knauer, Zur Frage nach der Unauflösigkeit der Ehe. Gibt es wirklich „Privilegium“ Paulinum?, 9 (2015), s. 467-469; K. Lüdicke, Der neue kirchliche Eheprozess. Evolution oder Revolution?, 10 (2015), s. 509-512; V. Resing, Es ist nicht wie vorher, 11 (2015), s. 556n.

2 Por. J. Auer, Allgemeine Sakramentenlehre und das Mysterium der Eucharistie, Regensburg ${ }^{2} 1974$, s. 43n; A. Gerhards, Stationen der Gottesbegegnung. Zur theologischen Bestimmung der Sakramentenfeiern, [w:] Die Feier der Sakramente in der Gemeinde. Festschrift für Heinrich Rennings, M. Klöckner, W. Glade (red.), Kevelaer 1986, s. 19n.

Por. R. Lachner, Communio - eine Grundidee des christlichen Glaubens. Ein Beitrag zur Elementarisierung im Fach Dogmatik, [w:] Qualitätsmanagement in der Theologie. Chancen und Grenzen einer Elementarisierung im Lehramtsstudium, R. Lachner, E. Spiegel (red.), Kevelaer 2003, s. 230; H. O. Meuffels, Kommunikative Sakramententheologie, Freiburg Basel - Wien 1995; M. Jagodziński, Sakramenty w stużbie communio. Studium teologiczno-komunikacyjne, Warszawa 2008.

4 C. S. Bartnik, Dogmatyka katolicka, t. II, Lublin 2003, s. 594n.

5 Por. A. Schilson, Katholische Sakramententheologie auf neuen Wegen? Bemerkungen zu einer Neuerscheinungen, „Herder Korrespondenz“ 33 (1979), s. 571n; M. Jagodziński, Sakramenty komunii, „Ruch Biblijny i Liturgiczny” 4 (2009), s. 285-288. 
każdy ma swoje żywotne miejsce ${ }^{6}$. Ponieważ wszystkie sakramenty służą budowaniu komunii - w nawiązaniu do Katechizmu i w konsekwentnym dopełnieniu - ich charakter komunikacyjno-komunijny można ukazać grupując je w sakramenty „wtajemniczenia w komunię”, „uzdrowienia komunii” i „służby komunii”. Powstaje w ten sposób następująca struktura: sakramenty wtajemniczenia w komunię: chrzest - sakrament początku komunii, bierzmowanie sakrament umocnienia komunii, Eucharystia - sakrament budowania komunii; sakramenty uzdrowienia komunii: pokuta - sakrament przywrócenia komunii? namaszczenie chorych - sakrament podtrzymania komunii; sakramenty służby komunii: święcenia - sakrament „urzędowej” posługi komunii, małżeństwo sakrament małżeńsko-rodzinnej służby komunii ${ }^{8}$.

\section{Personalistyczny fundament sakramentu małżeństwa}

Współczesna antropologia uwzględnia rzeczywistość osobową i międzyosobową człowieka9 ${ }^{9}$ oraz dokonuje wręcz nowej interpretacji osoby ludzkiej. Człowiek staje się sobą w komunikacji z drugim człowiekiem i dzięki temu powstaje wspólnota konieczna do bycia sobą ${ }^{10}$. Teologia podkreśla, że w człowieku odbija się komunikacyjna i komunijna istota Boga ${ }^{11}$, a $z$ tego wypływa komunikacyjny $^{12}$ i komunijny wymiar bycia człowiekiem ${ }^{13}$.

$6 \quad$ Por. KKK 1211.

7 Zob. M. Jagodziński, Komunijna wizja sakramentu pokuty i pojednania, [w:] Czy można dzisiaj wzywać do nawrócenia i pokuty? Chrześcijańska odpowiedź wiary, M. Składanowski, T. Syczewski, J. Połowianiuk (red.), Lublin 2015, s. 73-93.

8 Idem, Sakramenty w stużbie communio, op. cit., s. 336-338; idem, Sakramenty komunii, op. cit., s. 288-293.

Por. A. Perzyński, Włoska antropologia teologiczna. Studium historyczno-dogmatyczne, Łódź 2012, s. 12 n.

10 Por. P. Eicher, Die anthropologische Wende. Karl Rahners philosophischer Weg vom Wesen des Menschen zur personaler Existenz, Freiburg (Schweiz) 1970, s. 98-110; T. Schneider, Znaki bliskości Boga. Zarys sakramentologii, Wrocław 1990, s. 11n; M. Jagodziński, Sakramenty w stużbie communio, op. cit., s. $171 \mathrm{n}$.

11 Por. R. Lachner, Communio..., op. cit., s. 239.

12 Por. W. Hryniewicz, Pascha Chrystusa w dziejach człowieka $i$ Wszechświata. Zarys chrześcijańskiej teologii paschalnej, t. 3, Lublin 1991, s. 241.

13 Por. C. Valverde, Antropologia filozoficzna, Poznań 1998, s. 349: „Człowiek jest przyporządkowany człowiekowi i tylko w drugim człowieku odnajduje siebie samego. Tylko transcendując samego siebie w poszukiwaniu «ty», człowiek realizuje własne bycie. [...] relacja «ja-ty» jest relacją w pełnym znaczeniu tego słowa. Jest spotkaniem osób; nie oznacza czynienia z drugiego człowieka przedmiotu, który można posiadać, albo którym można manipulować. Oznacza kontemplowanie i pełną szacunku akceptację, oświecającą obecność, bezpośrednią relację bez pośredników (ekonomicznych, politycznych, erotycznych 
Już stworzenie człowieka ma wymiar komunijny ${ }^{14}$. Komunijny wymiar ma także osoba człowieka. Ma ona charakter relacyjny i ekstatyczny, co potwierdza nawet analiza językowa - greckie prósopon oznaczało bezpośrednią relację do kogoś lub czegoś. Pierwotna treść tego słowa wyklucza rozumienie osoby jako jednostki bez żadnego odniesienia do innej rzeczywistości. Chodzi tu o relację jako różnicę gatunkową w sensie wydarzenia, które wprowadza osobę w stan odniesienia. Pojęcie osoby jest więc terminem ontologicznym o charakterze relacyjnym i zakłada relację osoby do innego podmiotu lub przedmiotu. Dlatego należy pojmować osobę jako egzystencjalną relację, jako specyficzny sposób istnienia natury objawiający się $\mathrm{w}$ relacji oraz w zdolności do wchodzenia w kontakt i we wspólnotę ${ }^{15}$. Osoba to nie tylko bycie i trwanie, lecz także wyjście w kierunku komunii z innymi, a ludzka natura stanowi warunek i podstawę wzajemnej solidarności, empatii, wspólnego doświadczania, komplementarności i budowania komunii ${ }^{16}$. Szczególnie chrześcijanin jest człowiekiem ekstatycznym i nosi w sobie rysy jednoznacznie komunijne ${ }^{17}$.

itp.), którzy przeszkadzaliby prawdziwemu spotkaniu z «ty». Jest relacją, w której każdy zachowuje wolność, ale angażuje całą swą osobę. Kiedy mówię «ty», mówię także «ja». «Ty» czyni «ja». We wzajemnej relacji oboje zyskujemy świadomość własnego bycia osobami. Czujemy się w niej poznającymi i poznawanymi, kochającymi i kochanymi, w niej wybieramy i jesteśmy wybierani, korzystamy z wolności wobec drugiego człowieka i on uznaje nas za wolnych. W tej relacji chcę, abyś ty był tobą, to znaczy kimś innym niż ja, a ty chcesz, bym ja był mną, kimś innym niż ty. W ten sposób obaj tworzymy «my», komunię osób, opartą na tożsamości współodpowiedzialności. Kategorią ontologiczną, która dostarcza racji dostatecznej «my», jest pomiędzy - prawdziwy egzystencjał w znaczeniu heideggerowskim. Ale najgłębszą realnością «pomiędzy» jest miłość, rozumiana nie tylko jako uczucie, ale także jako komunia”. Por. M. Jagodziński, Komunijny wymiar osoby ludzkiej, „Roczniki Teologiczne”, t. LXI, z. 2 (2014), s. 51-63; idem, Antropologia komunijna, Lublin 2015, s. 5-7. Zob. wyjaśnienie pojęcia „komunia” ibidem, s. 11-13.

Por. M. Jagodziński, Antropologia komunijna, op. cit., s. 15-20.

Por. W. Hryniewicz, Pascha Chrystusa..., op. cit., s. 67.

M. Jagodziński, Antropologia komunijna, op. cit., s. 47: „Biblijny przekaz Księgi Rodzaju potwierdza, że w strukturę człowieka wpisana jest pewna diadyczność, dwubiegunowość będąca szczególnym wyrazem i najpełniejszym urzeczywistnieniem dialogiczności. Można powiedzieć, że ludzką strukturę charakteryzuje nieustanne napięcie między tożsamością a różnicą, które przejawia się w pewnych konstytutywnych biegunowościach antropologicznych: duch-ciało, mężczyzna-kobieta, jednostka-wspólnota. Podstawowy egzystencjał osoby ludzkiej stanowi to napięcie, będące postawą i elementem oraz ciągle urzeczywistniające się w relacji. Człowiek uświadamia sobie, że musi nieustannie szukać swojego dopełnienia w przeciwstawnym biegunie".

Por. J. Szymik, Religio vera. Rzeczywistość chrześcijaństwa - chrześcijański wymiar rzeczywistości wedlug Josepha Ratzingera/Benedykta XVI, „Teologia w Polsce” 7 (2013) nr 2, s. 8-10; M. Jagodziński, Antropologia komunijna, op. cit., s. 21-28. 
Ma to ogromne znaczenie dla małżeństwa, gdyż osoba ludzka jest nacechowana płciowością ${ }^{18}$. Oryginalną wizję ludzkiej płciowości zawiera list Jana Pawła II Mulieris dignitatem, według którego mężczyzna i kobieta są obrazem Boga także jako jedność dwojga. Papież poszerzył klasyczną wizję człowieka jako podmiotu osobowego przez potraktowanie pierwotnego zróżnicowania płciowego jako konstytutywnej części podobieństwa do Boga: „obrazem i podobieństwem Boga stał się człowiek nie tylko przez samo człowieczeństwo, ale także przez komunię osób, którą stanowią od początku mężczyzna i kobieta"19. Dzięki temu także prokreacja ludzka odróżnia się od prokreacji zwierzęcej, bowiem owocem małżeńskiej komunii miłości jest nie jakiś osobnik, lecz człowiek będący obrazem Bożym. Każda ludzka istota jest osobą komunijną, ontologicznie otwartą na komunię z innymi, ponieważ ontologicznie jest zależna od komunii ze Stwórcą. Komunia między mężczyzną i kobietą, będąca pierwotnym wyrazem wszelkiej możliwej komunii między ludźmi, urzeczywistnia obraz Trójcy Świętej, gdy opiera się na miłości Boga. Przybrani synowie i córki Boga, którzy żyją w komunii, aktualizują ten wymiar obrazu Boga, który dopełnia się w wybitny sposób w komunii małżeńskiej ${ }^{20}$. Odmienność płci umożliwia więc tworzenie communio personarum. Dzięki stworzeniu komunii osób pierwszych rodziców dzieło stworzenia zostało doprowadzone niejako do końca ${ }^{21}$. Samotność człowieka w jahwistycznym opisie człowieka to nie tylko pierwsze odkrycie właściwej dla osoby transcendencji, lecz także odkrycie relacji do osoby jako otwarcia i oczekiwania na komunię osób. Jedność poprzez ciało wskazuje także na wcieloną komunię osób i tę komunię postuluje ${ }^{22}$. Jan Paweł II w liście do

18 Idem, Antropologia komunijna, op. cit., s. 59n: „człowiek nie jest monadą, lecz raczej ukonstytuowany jest jako istota relacyjna, oparta na komunikacji, przekazie, komunii, wzajemnym udziale, wspólnocie. Już w fakcie istnienia dwu płci ujawnia się jego wymiar relacyjny i komunialny. Bycie człowiekiem realizuje się w byciu mężczyzną i kobietą we wzajemnej korelacji. Odmienność płci jest nie tylko związana ze wzajemnym odkryciem swojej tożsamości, lecz pozwala także na realizowanie istotnej cechy osoby ludzkiej, jaką jest umiejętność dawania siebie i budowania komunii osób. «Rzeczywistość Bożego obrazu nie wyczerpuje się w strukturze bytu człowieka, ale domaga się przyjęcia perspektywy dynamicznej, dialogicznej, komunijnej». Człowiek jest obrazem i podobieństwem Boga nie tylko przez swe człowieczeństwo, lecz także przez komunię osób, odzwierciedla Boga nie w akcie samotności, lecz w akcie tej komunii”.

Jan Paweł II, Mężczyzna i niewiasta stworzyt ich. Odkupienie ciała a sakramentalność matżeństwa, T. Styczeń (red.), Lublin 2008, s. 33.

20 Por. A. Scola, Osoba ludzka. Antropologia teologiczna, Poznań 2005, s. 188-190; S. Kunka, Teologiczna wizja cielesności czlowieka w nauczaniu Karola Wojtyly - Jana Pawła II, Lublin 2012, s. 36-65.

21 Por. S. Kunka, Teologiczna..., op. cit., s. 39.

22 Por. ibidem, s. 41n; M. Jagodziński, Antropologia komunijna, op. cit., s. 51: „Ciało wyraża kobiecość dla męskości i męskość dla kobiecości oraz ułatwia wzajemność i komunię 
rodzin Gratissimam sane ( $\mathrm{nr}$ 8) napisał, że według Rdz 2,24 dwa somatycznie różne podmioty stają się „,jednym ciałem”, uczestniczą w zdolności do życia w prawdzie i miłości. Zdolność ta odzwierciedla osobową konstytucję człowieka i predysponuje go do kształtowania komunii osób. Okrzyk mężczyzny na widok kobiety „Ta dopiero jest kością z moich kości i ciałem z mego ciała!” (Rdz 2,23) oznacza, że ciało wyraża kobiecość dla męskości i męskość dla kobiecości, a przez to ułatwia wzajemność i komunię osób ${ }^{23}$.

Procesy zachodzące we współczesności nie sprzyjają nieodwołalności decyzji małżeńskiej. Nierozerwalność jest nie tyle normatywnym oczekiwaniem, co raczej żądaniem stawianym wzajemnie przez małżonków ufających swojej miłości. Taka decyzja życiowa zakłada wolne i definitywne określenie woli, aby nie stawiać żadnych granic wzrostowi ich miłości. Właściwą podstawą nierozerwalnej i nieodwołalnej wspólnoty na całe życie jest to, że jest ona wyrazem osobowej prawdy dwojga ludzi, którzy chcą szanować i uznawać siebie jako osoby. Nierozerwalność małżeństwa i jego jedność oparte są na nieuwarunkowanym przyjęciu i potwierdzeniu partnerów. Istotne cechy małżeństwa - jego wyłączność (monogamia), brak jakichkolwiek zastrzeżeń i gotowość na wspólną przyszłość - wynikają z tego, co w języku nauk społecznych nazywane jest „włączeniem całej osoby” (Niklas Luhmann). Nie chodzi więc, jak w innych formach ludzkiego uspołecznienia, o czasowe współdziałanie na jakimś odcinku życia, lecz o bezwarunkowe przyjęcie mężczyzny i kobiety ze wszystkimi aspektami ich bycia osobami. Oznacza to żądanie całkowitej przynależności i najwyższej przejrzystości własnego bycia sobą, które szuka w miłości swojego spełnienia, a jego „maszynerią” jest seksualnośćc

Decydującą podstawą konieczności włączenia przeżyć seksualnych w przestrzeń partnerskiego odniesienia nacechowanego trwałą wiernością jest to, że mamy w nich do czynienia $z$ drugim człowiekiem, a nie przedmiotem, którego można „używać”. Należy więc, także w nacechowanym przyjemnością współbyciu seksualnym, „radować się” obecnością drugiego, co odpowiada godności jego osoby. Egzystencjalne znaczenie popędu seksualnego polega na tym, że skierowany jest on ku osobie przeciwnej płci i może stać się podstawą trwałego

osób, a komunia małżeńska zakorzeniona jest w naturalnych więzach ciała i krwi. Ciało samo w sobie nie jest wyrazem Bożego podobieństwa i obrazu - Bóg nie ma ciała. Ponieważ jednak ciało należy do natury człowieka i bierze udział w realizowaniu się osoby ludzkiej dzięki komunii z innymi osobami, uczestniczy w tym obrazie i podobieństwie. Perspektywa trynitarna, zakładająca przedmiotowy («strukturalny») status obrazu Bożego w człowieku, implikuje jego status komunijny («relacyjny»)”.

23 Por. Jan Paweł II, Mężczyzna i niewiasta stworzyt ich..., op. cit., s. 48; M. Jagodziński, Antropologia komunijna..., op. cit., s. 28n.

24 Por. E. Schockenhoff, Liebe auf Abwegen? Zum Verhältnis von Sexualität und Liebe in intimen Beziehungen, „Theologisch-praktische Quartalschrift” 4 (2015), s. 339-343. 
odniesienia. Dlatego też seksualność nie może być pojmowana analogiczne do głodu i pragnienia, lecz raczej w kategoriach języka i komunikacji. Jako najintensywniejsza forma ludzkiej komunikacji podlega ona podstawowemu wymaganiu prawdziwości, w której mężczyzna i kobieta wyrażają swoją wzajemną skłonność. Seksualność jest więc zawsze, także jako pożądliwa miłość w formie seksualnej, relacją między osobami w ich pełni bytu. Służy ona spełnieniu podstawowej ludzkiej potrzeby zbudowania przestrzeni ochronnej dla intymności i powierzenia siebie oraz dostarcza przy okazji podstawowych doświadczeń schronienia, bezpieczeństwa, a także odpowiedzialności i oddania się drugiemu. Pomaga ludziom, aby jako mężczyźni i kobiety odkryli konkretne miejsce, w którym odnajdą swoje zadanie życiowe oraz połączą bycie sobą $z$ bytowaniem w świecie. Sam fakt natomiast, że mężczyzna lub kobieta stają się wtedy także obiektem pożądania, nie niszczy jeszcze ich godności osobowej. Kochający partner chce bowiem także, aby był wzajemnie pożądany, nie chce spotkać się z obojętnością czy respektem tylko. Doświadczenie własnej atrakcyjności dla partnera przyczynia się raczej do przeżycia własnej wartości, jest pożądane i oznacza w języku seksualnego pożądania: „Chcę ciebie, bo jest dobrze dla mnie, że tu jesteś”. Wzajemne pożądanie zakłada, że partnerzy są dla siebie pożyteczni, jakkolwiek nie w sensie używania przedmiotu. Jeśli pożądanie zakorzenione jest w osobowym, trwałym i wiernym odniesieniu, oznacza wzajemne potwierdzenie partnerów w miłości. Nie oznacza posiadania partnera dla siebie, lecz pożądanie kogoś, komu się oddało siebie i oczekuje się od niego jego wzajemnego oddania. Eberhardt Jüngel napisał krótko: „W miłości nie ma żadnego posiadania, które nie wyrastałoby z oddania"25. Jeśli seksualne pożądanie drugiego łączy się z miłością, wychodzi poza siebie, co odpowiada ekstatycznej strukturze pożądania połączonego z byciem przy innym, które cechuje pożądanie miłości ${ }^{26}$.

Relacyjny i ekstatyczny charakter ludzkiej osoby ukazuje wnikliwie personalizm dialogiczny ${ }^{27}$, stojący u podstaw filozofii dialogu i spotkania. Podstawową prawdę o osobie odsłania analiza spotkania międzyosobowego. Osoba ludzka szuka osobowego „ty”, dzięki któremu uświadamia sobie swoją inność i odrębność. Przekraczając samego siebie i wchodząc w dialog z drugą osobą w ostatecznym odniesieniu do Boga jako „wiecznego Ty” - człowiek aktualizuje i konstytuuje siebie. Oznacza to rewaloryzację kategorii relacji, wprowadzenie miłości do określenia osoby i wskazanie na zależność ludzkiego „ja” od

\footnotetext{
25 E. Jüngel, Gott als Geheimnis der Welt, Tübingen 1977, s. 437.

26 Por. E.Schockenhoff, Liebe auf Abwegen? Zum Verhältnis von Sexualität und Liebe in intimen Beziehungen, 343-345. Por. także Benedykt XVI, encyklika Deus caritas est (2005), s. 11.

27 Por. C. S. Bartnik, Dogmatyka katolicka, t. I, Lublin 2000, s. 408.
} 
spotkania z „ty” i „my”. Kiedy Bóg stworzył człowieka, nawiązał z nim dialog. Otworzył się na człowieka i widzi w nim partnera rozmowy. Człowiek musi więc miary samego siebie szukać w Bogu. W ten sposób obraz Boży w człowieku zawiera relację, partnerstwo, komunię osób ${ }^{28}$. Relacyjność jest konstytutywną cechą bytu osobowego, dla którego istotne jest otwarcie się na inne osoby, ścisła więź i głębokie zjednoczenie (communio personarum). Osoby Boskie dzielą się $z$ ludźmi swoim bytem osobowym, są dla nich modelem pełnej doskonałości osobowej i włączają je do swojej Komunii ${ }^{29}$. Prakategorią rzeczywistości osoby jest więc nie antyczna substancja czy nowożytny podmiot, lecz relacja ${ }^{30}$.

Pogłębiona analiza międzyosobowej komunii wskazuje, że między „ja” i „ty” mieści się zawsze jakieś „pomiędzy”, inne od obu zasadniczych członów relacji i jednocześnie na nie wskazujące, bez którego (jako „trzeciego”, w którym obydwa łączą się w „my”) nie mogą się obejść - osoby stają się wręcz sobą w czymś „trzecim”, co je jednoczy. Ten „trzeci element” zawsze ma u podstaw coś głębszego - nową więź osobową. W miłości np. nie kocha się tylko drugiego (i siebie), lecz także wzajemną wspólność. Ta więź osiąga swój szczyt wtedy, gdy staje się osobą ${ }^{31}$, która „reprezentuje” osobowo wspólny świat partnerów relacji oraz ich ponadosobową łącznośćc ${ }^{32}$. Okazuje się więc, że każde wydarzenie

28 Por. G. Barth, Hermeneutyka osoby, Lublin 2013, s. 137-139.

29 Por. M. Rusecki, Personalizm. II. W teologii, [w:] Encyklopedia katolicka, t. XV, E. Gigilewicz i in. (red), Lublin 2011, s. 333-335; M. Jagodziński, Antropologia komunijna, op. cit., s. $34 n$.

30 Por. B. Gacka, Znaczenie osoby w teologii Josepha Ratzingera - Benedykta XVI, Warszawa 2010, 25-30, s. 124n. Autor wyróżnił w myśli teologicznej J. Ratzingera dwa ujęcia osoby: jako subsystencji (przekład greckiego hypostasis) i jako relacji.

31 C. K. Norwid, Człowiek: „- Rodziców miłość, jak trzecia istota, Z dwóch serc ku niebu powstająca kwiatem..." (http://www.poezja.org/utwor-4661.html).

32 Por. G. Greshake, Trójjedyny Bóg. Teologia trynitarna, tł. J. Tyrawa, Wrocław 2009, s. 134-144; M. Jagodziński, Trialogiczno-komunijna koncepcja trynitologii, „Studia Diecezji Radomskiej” t. X, Radom 2010/2011, s. 60n. G. Barth, Hermeneutyka..., op. cit., s. 174: „Znaczenie trzeciego faktora stanowiącego relację do świata staje się wyraźniejsze, kiedy zmierza i w kierunku więzi osobowej. Powstaje ona [...] «pomiędzy» «ja» i «ty» jako swoistego rodzaju «rezultat» relacji i spotkania. Oczywiście, swój zewnętrzny wyraz uzyskuje w formie zarówno nowego doświadczenia i kształtowania świata, jak i w języku, ale jej podstawą i treścią zarazem jest miłość. Otóż, «ja» i «ty» nie tylko kochają siebie nawzajem, ale również to, co «pomiędzy» nimi, czyli osobowa wspólność «ja» i «ty». Owo trzecie krystalizuje się jako więź, która reprezentuje (osobowo!) wspólny świat «ja» i «ty», mogący przyjąć postać konkretnej osoby (Boga jako instancji dwojga małżonków czy dziecka wobec rodziców) bądź też jakiejś szczególnej wartości, która zespala świat osób. Bycie we dwoje nie tylko, że nie wyklucza trzeciego/trzeciej osoby, ale przyjmuje go i włącza, aby mogło się rozwijać. Dwoje doznaje wręcz radości, że może udzielić mu przestrzeni w tym rozwoju. Trzeci/trzecia zaś raduje się w swoim byciu obdarowanym jako wspólnym byciu dwojga". 
międzyosobowe jest nie tylko w istotny sposób dwubiegunowe, lecz trójbiegunowe. Na tym polega też istota międzyosobowej komunii: wszystkie konstytutywne elementy wzajemnie się indywidualizują i jednocześnie osiągają jedność całości, a poszczególne elementy i całość dają się ująć tylko trialektycznie ${ }^{33}$.

Istnieje jednak także głębszy wymiar wspomnianego „trzeciego-pomiędzy”, który ma także ogromne znaczenie dla małżeństwa sakramentalnego. Chodzi o Trójjedynego Boga, bez którego „trialogicznego życia” i jego odbicia w ludzkim świecie osoby nie byłaby możliwa trialogiczna struktura bytu osobowego i realizacja trialogicznie-,trynitarnej” komunii ${ }^{34}$. Wybitny teolog wschodni Joannis D. Zizioulas twierdzi, że pełne człowieczeństwo osoba osiąga dzięki temu, że może uczestniczyć w trynitarnym życiu Boga ${ }^{35}$. Skoro istotą Boga jest Komunia - istotą osoby ludzkiej jest także komunia, co też powoduje, że teologię osoby i małżeństwa powinno się pogłębiać przez umieszczanie jej w ramach trynitarnej hermeneutyki pojęć „relacji” i „wspólnoty” ${ }^{36}$. Punktem zwrotnym w odkryciu tej struktury osobowej było oczywiście chrześcijańskie Objawienie. W ten sposób zostało wydobyte na pole świadomości coś, czego nie wychwyciła dostatecznie ani filozofia współczesna, ani nawet sama filozofia chrześcijańska ${ }^{37}$.

33 Por. G. Greshake, Trójjedyny Bóg..., op. cit., s. 139n; M. Jagodziński, Antropologia komunijna, op. cit., s. 39-41.

Por. ibidem, s. 141-142.

Por. J.D. Zizioulas, Human Capacity and Human Incapacity: A Theological Exploration of Personhood, „Scottish Journal of Theology” 28 (1975), s. 407n. Osoba nie może egzystować bez communio, „tkwi nie w indywidualnej egzystencji, ale w interakcji do Boga i stworzenia: człowiek nie jest żyjącym bytowaniem bez powiązania z innymi osobami. Człowiek staje się stworzeniem relacyjnym i realizującym swoje bycie jako stworzenie w komunii. Tylko wówczas uzyskuje prawdziwie ontologiczne istnienie..." (G. Barth, Hermeneutyka..., op. cit., s. 164n).

Por. G. Barth, Hermeneutyka..., op. cit., s. 162n. Pojęcia te „opierają się na fundamencie ontologicznym, znajdującym się w trynitarnym byciu Boga, który ostatecznie oznacza perychoretyczną komunię. Historyczny dostęp do tego ontologicznego obrazu wspólnoty mamy [...] przede wszystkim we wcielonym Synu oraz Kościele. Droga odgórna [od Boskiej do ludzkiej wspólnoty) stanowi podstawę rozumienia ludzkiej osobowości - każdego z członków Kościoła, a następnie osobowości wszystkich ludzi na świecie. [...] jeśli Kościół zawiera w sobie obraz Bożej wspólnoty i jeśli człowiek jest osobą stworzoną na obraz Boga, a ostatecznie - na obraz Boga, który jest komunią, to człowiek teologicznie jest osoba tylko wtedy, gdy jego osobowość odzwierciedla osobowość Boga jako wspólnoty" (ibidem, s. 163).

37 Ibidem, s. 168n: „J. Ratzinger twierdzi, że w chrześcijaństwie nie istnieje prosta zasada dialogiczna w nowoczesnym rozumieniu «ja»-«ty», taka zasada nie istnieje także w przypadku człowieka umieszczonego w kontekście dziejów, w szerokim «my», ani też w przypadku Boga, który [...] nie jest zwykłym «Ty», lecz właściwe «My» Ojca, Syna i Ducha Świętego. Ludzkie «ja», a nawet nasze ludzkie «ja»-«ty» jako dialogiczna relacja ukryte są w Boskim 


\section{Sakrament małżeństwa jako działanie komunikacyjne}

Sakrament małżeństwa jest aktem działania komunikacyjnego, które z zasady musi cechować wzajemne uznanie równouprawnienia partnerów komunikacji, nakierowanie na powszechną wspólnotę komunikacji oraz antycypację przyszłości przy uwzględnieniu i przetworzeniu przeszłości, a na skutek jego krytycznego odniesienia do świata zewnętrznego powstaje nowa konfiguracja w przestrzeni społecznej ${ }^{38}$.

Apriorycznym sensem prawdziwej komunikacji jest wzajemne uznanie siebie. Jeśli dwoje ludzi przyrzeka coś sobie wzajemnie, to uznają to założenie i realizują w życiu. Przysięgi małżeńskiej nie można więc złożyć jednostronnie i obustronnie nawet wymówićs ${ }^{39}$. Monogamiczne równouprawnienie małżonków jest najbardziej uwydatnione w nauce św. Pawła, według której kobiecie i mężczyźnie wolno wiązać się w małżeństwie tylko z jedną osobą, a małżonkowie mają takie same wzajemne prawa do ciała współmałżonka (por. 1 Kor 7,3n). Ewentualna decyzja o czasowej abstynencji we współżyciu musi być więc uzgodniona także dwustronnie (por. 1 Kor 7,5) ${ }^{40}$. Te same prawa mają wdowcy i wdowy, którym wolno wstąpić w ponowny związek małżeński (por. 1 Kor 7,8n). Kobiecie nie wolno odchodzić od mężczyzny, a mężczýnie od kobiety (por. 1 Kor 7,10n). Takie same reguły dotyczą zgody na współżycie lub odejście strony niewierzącej (tzw. przywilej Pawłowy ${ }^{41}$ ) (por. 1 Kor 7,12-13.15). Tak samo oceniany jest stan bezżenny kobiety i mężczyzny: (por. 1 Kor 7,27.33n) ${ }^{42}$. Paweł pisze wprawdzie, że „mężczyzna jest głową kobiety” (1 Kor 11,3) i że „nie mężczyzna powstał $z$ kobiety, lecz kobieta z mężczyzny. [...] mężczyzna nie został stworzony dla kobiety, lecz kobieta dla mężczyzny" (1 Kor 11,8n), jednak kilka wierszy dalej

«My». [...] wraz z trynitarnym «My» zostało przygotowane miejsce pod każde ludzkie «my» [...] Wyrywa ono osobę z jeszcze (!) indywidualistycznego związku «ja»-«ty», w którym może dojść nawet do zatracenia «ty». [...] chodzi o uchwycenie istotnego momentu, który z punktu widzenia relacji Bosko-ludzkiej wnosi istotne światło na rozumienie osobowej relacji, gdzie «ja» i «ty», wspólne bycie ze sobą, prawdziwa communio będzie najbardziej pierwotnym sposobem wszelkiego osobowego bycia. Ujawnia się wtedy triadyczna struktura i dynamika (triadyczność) osoby. Między «ja» i «ty» wchodzi trzeci element, dzięki któremu i w którym dopiero «ja» i «ty» mogą odnieść się do siebie nawzajem oraz do siebie samego w pełni wolności z uznaniem”. Por. M. Jagodziński, Antropologia komunijna, op. cit., s. 41-43.

Por. R. Schaeffler, P. Hünermann, Ankunft Gottes und Handeln des Menschen. Thesen über Kult und Sakrament, Freiburg - Basel - Wien 1977, s. 57. 
dodaje: „u Pana ani mężczyzna nie jest bez kobiety, ani kobieta nie jest bez mężczyzny. Jak bowiem kobieta powstała z mężczyzny, tak mężczyzna rodzi się przez kobietę" (1 Kor 11,11n). Tę samą myśl w innym kontekście wyraża Ga 3,28: „Nie ma już Żyda ani poganina, nie ma już niewolnika ani człowieka wolnego, nie ma już mężczyzny ani kobiety, wszyscy bowiem jesteście kimś jednym w Chrystusie Jezusie." O równouprawnieniu małżonków świadczy też polecenie: „Bądźcie sobie wzajemnie poddani w bojaźni Chrystusowej!” (Ef 5,21) ${ }^{43}$.

Mężczyzna i kobieta $z$ woli Boga łączą się na całe życie, tworząc nierozerwalną wspólnotę małżeńsko-rodzinną (por. Mk 10,6-9). Katechizm komentuje wynikające $z$ tego zadanie wierności: „Związanie się na całe życie $z$ drugim człowiekiem może wydawać się trudne, a nawet niemożliwe. Tym ważniejsze jest głoszenie Dobrej Nowiny, że Bóg nas kocha miłością trwałą i nieodwołalną, że małżonkowie mają udział w tej miłości, że Bóg ich prowadzi i podtrzymuje oraz że przez swoją wierność mogą oni być świadkami wiernej miłości Boga. Małżonkowie, którzy z pomocą łaski Bożej dają to świadectwo, często w bardzo trudnych warunkach, zasługują na wdzięczność i wsparcie wspólnoty eklezjalnej”"44. Małżonkowie nie są więc sami, gdyż dzięki sakramentowi mają wsparcie ze strony Boga, a ich wspólnota komunikacji małżeńskiej zostaje włączona w komunikacyjną wspólnotę całego Kościoła ${ }^{45}$.

Przysięga małżeńska ustanawia związek i sens społeczny, który obejmuje teraźniejszość i przyszłość oraz potrzebuje czasu, aby mógł się zrealizować ${ }^{46}$. Bardzo bogaty w treść jest tekst Ef 5,25-32. „Wielka tajemnica” związku dwojga ludzi, przyrównanego do związku Chrystusa z Kościołem, sprawia, że małżonkowie przestają być zwykłymi tylko ludźmi, a wszystkie ich działania $\mathrm{i}$ istota małżeństwa zostają wyniesione do sfery całkiem innych wartości, do świata nadprzyrodzonego ${ }^{47}$. Małżonkowie mają też własny dar w życiu Kościoła: „Właściwa łaska sakramentu małżeństwa jest przeznaczona dla udoskonalenia miłości małżonków i dla umocnienia ich nierozerwalnej jedności. Przez tę łaskę «podtrzymują się wzajemnie... z pomocą wiernej miłości, a przyjmowanemu

43 Por. ibidem, 226n; KKK 1645: „Przez równą godność osobistą kobiety i mężczyzny, która musi być uwzględniona przy wzajemnej i pełnej miłości małżonków, ukazuje się także w pełnym świetle potwierdzona przez Pana jedność małżeństwa" (Katechizm cytuje KDK 49). Por. M. Jagodziński, Sakramenty w stużbie communio..., op. cit., s. 395n.

KKK 1648. Por. C. Caffarra, Sakramentalna ontologia a nierozerwalność matżeństwa, [w:] Pozostaćw prawdzie Chrystusa. Matżenstwo i Komuniaw Kościele katolickim, R. Dodaro (red.), Poznań 2015, s. 166n.

Por. M. Jagodziński, Sakramenty w stużbie communio..., op. cit., s. 396.

Por. H.-J. Höhn, Spüren..., op. cit., s. 118n.

Por. KKK 1639. Por. K. Romaniuk, Sakramentologia..., op. cit., s. 230n, 233. 
z miłości do Boga potomstwu wpajają chrześcijańskie nauki i ewangeliczne cnoty»" 48 .

Najbardziej rewolucyjnym momentem w nauczaniu Jezusa o małżeństwie był wymóg zachowania nierozerwalności (por. Mk 10,2-9) ${ }^{49}$. Potwierdzają to wypowiedzi św. Pawła (por. 1 Kor 7,10n). Ta nauka Jezusa nie była (w stosunku do Starego Testamentu) aż tak wielkim nowatorstwem, przywróciła tylko małżeństwu jego pierwotną doskonałość odsuniętą na dalszy plan z powodu zatwardziałości serc. Przywrócenie tej pierwotnej doskonałości małżeństwa oznacza także przetworzenie wadliwych relacji komunikacyjnych, zaistniałych po upadku ludzi, w przestrzeni społecznej. $O$ zdecydowanie religijnym wymiarze małżeństwa sakramentalnego świadczy też jego mistyka nowotestamentalna, oparta zasadniczo na symbolice starotestamentalnej, zwłaszcza na metaforze zaślubin Boga z Izraelem ${ }^{50}$.

Według ustawodawstwa starotestamentalnego tylko mężczyzna mógł być zasadniczo podmiotem w procedurze rozwodowej i tylko on mógł pojmować jeszcze inne żony, natomiast według nauczania Jezusa każda ze stron dopuszcza się grzechu wiarołomstwa, jeśli opuszcza małżonka (Mk 10,11n; por. Łk 16,18). Ta zasada tworzy nową rzeczywistość w społecznej przestrzeni małżeństwa. Nowotestamentowe prawo małżeńskie przedstawia się skromnie w porównaniu $z$ drobiazgowymi przepisami prawa starotestamentowego, ale wnosi wiele jasnego światła do wspólnego pożycia małżonków, gwarantuje równość ich praw i obowiązków oraz respektuje godność każdej osoby ${ }^{51}$. Nauczanie Jezusa szczególnie mocno uwydatniło ideę jedności dwojga małżonków (por. Mt 10,7n). „Jedno ciało" oznacza, zgodnie z mentalnością semicką, po prostu człowieka, a wspólnota ciała zakłada również wspólnotę myśli i pragnień. Warto także podkreślić nawiązujące do początków ludzkości słowa Jezusa: „Co więc Bóg złączył, tego człowiek niech nie rozdziela!” (Mt 10,9). Nie chodziło Mu tylko o stworzenie i połączenie dwojga pierwszych ludzi. Dziełem Boga jest każde małżeństwo, On towarzyszy aktowi jego powstania i powołuje (stwarza) instytucję małżeństwa ${ }^{52}$. Sakrament małżeństwa działa przez całe życie małżonków,

$48 \quad$ KKK 1641. Por. KKK 1653: „Płodność miłości małżeńskiej obejmuje także owoce życia moralnego, duchowego i nadprzyrodzonego, jakie przez wychowanie rodzice przekazują swoim dzieciom. Rodzice są głównymi i pierwszymi wychowawcami swoich dzieci. Por. Sobór Watykański II, dekl. Gravissimum educationis, 3. W tym sensie podstawowym zadaniem małżeństwa i rodziny jest służba życiu”. Por. M. Jagodziński, Sakramenty w stużbie communio..., op. cit., s. 396n.

49 Por. K. Romaniuk, Sakramentologia..., op. cit., s. 200.

50 Por. ibidem, s. 229n.

51 Por. ibidem, s. 201-206.

52 Por. ibidem, s. 201. 
przetwarzając wspólnotę rodziny w komunię życia i miłości ${ }^{53}$. Katechizm Kościoła Katolickiego cytuje słowa Tertuliana: „ «Miłość małzeńska zawiera jakąś całkowitość, w którą wchodzą wszystkie elementy osoby - impulsy ciała i instynktu, siła uczuć i przywiązania, dążenie ducha i woli. Miłość zmierza do jedności głęboko osobowej, która nie tylko łączy w jedno ciało, ale prowadzi do tego, by było tylko jedno serce i jedna dusza. Wymaga ona nierozerwalności i wierności w całkowitym wzajemnym obdarowaniu i otwiera się ku płodności. Jednym słowem chodzi o normalne cechy charakterystyczne dla każdej naturalnej miłości małżeńskiej, ale w nowym znaczeniu, gdyż sakrament nie tylko je oczyszcza i wzmacnia, ale wynosi tak, że stają się wyrazem wartości prawdziwie chrześcijańskich»" ${ }^{54}$. Katechizm mówi dalej, że dzięki wszystkim członkom dom rodzinny staje się ,pierwszą szkołą życia chrześcijańskiego i «szkołą bogatszego człowieczeństwa» ${ }^{55}$. W nim dziecko uczy się wytrwałości i radości pracy, miłości braterskiej, wielkodusznego przebaczania, nawet wielokrotnego, a zwłaszcza oddawania czci Bogu przez modlitwę i ofiarę ze swego życia"56.

\section{Sakrament małżeńsko-rodzinnej służby komunii}

Komunikacyjno-teologiczne wymiary sakramentu małżeństwa należy ukazywać w oparciu o przesłanki biblijne. Stworzenie kobiety (por. $\mathrm{Rdz} 2,18,21-25$ ) dało mężczyźnie osobową partnerkę. Późniejszy opis stworzenia (por. $\operatorname{Rdz} 1,27$ ) ukazuje dwupłciowego człowieka jako obraz Boga. Dla proroków łączność małżeńska była znakiem Przymierza z Bogiem i Jego wierności, a jednocześnie niewierności Ludu Wybranego (por. np. Oz 1; 3; Jer 2; 3; Ez 16; Iz 54; 62). W teologii stworzenia i Przymierza komunia mężczyzny i kobiety (por. $\mathrm{Rd} z$ 2,12) ma szczególny walor teologiczny ${ }^{57}$.

Miłość potrzebuje obietnicy, która ratuje jednostki przed destrukcyjnymi skutkami indywidualizmu. Chodzi tu o miłość, wierność i sprawiedliwośćn ${ }^{58}$. Według teologii katolickiej, sakramentu udzielają sobie sami małżonkowie

53 Por. A. A. Napiórkowski, Misterium communionis. Eklezjalny paradygmat dziejów zbawienia, Kraków 2006, s. 251-257.

KKK 1643. Por. Jan Paweł II, adhortacja apostolska Familiaris consortio, 13.

Sobór Watykański II, konstytucja Gaudium et spes, 52.

KKK 1657. M. Jagodziński, Sakramenty w stużbie communio..., op. cit., s. 397-399; idem, Antropologia komunijna, op. cit., s. 136n.

Por. H.O. Meuffels, Kommunikative..., op. cit., s. 331n; M. Jagodziński, Sakramenty w stużbie communio..., op. cit., s. 399.

Por. H.-J. Höhn, Spüren..., op. cit., s. 118. 
poprzez wzajemny „konsens”. Powaga miłości ${ }^{59}$ żąda bezwarunkowego uznania godności drugiej osoby, co wyraża właśnie obustronnie wypowiedziana przysięga małżeńska ${ }^{60}$, a ponieważ nie można jej wycofać ${ }^{61}$, sakrament małżeństwa staje się podstawą rodziny jako komunii życia i miłości62.

Właściwa sakramentalność małżeństwa opiera się na Chrystusie (por. Mk 10,2-9; Ef 5,21-33). Człowiek zostaje przyporządkowany Panu na wzór Jego relacji do ludzi, a podstawą tej dwustronnej relacji komunii ( $z$ włączeniem relacji małżeńskiej) jest misterium Zbawienia ${ }^{63}$. 1 Kor 7,3-5 opisuje ścisłą komunię płci opartą na nieustannej komunikacji. Natomiast Ef 5,21-33 trzeba interpretować w świetle Ef 4,5, który ukazuje chrzest jako fundament wiary i małżeństwa. Opis małżeństwa stał się pomostem do wprowadzenia analogii Chrystus-Kościól. Wspomnienie o „tajemnicy wielkiej” (Ef 5,32), odnoszące się do relacji Chrystus-Kościól, pozwala rozumieć sakramentalność małżeństwa w relacji do chrztu i Eucharystii jako swoiste zagęszczenie tajemnicy Zbawienia ${ }^{64}$. To interaktywne wydarzenie komunikacji jest włączone w obejmującą je relację między Bogiem a ludźmi i otrzymuje przez to swój właściwy charakter ${ }^{65}$, a źródłem i wzorem wszelkiej autentycznej komunii między ludźmi jest Trójjedyny Bóg ${ }^{66}$.

Pierwszym i bezpośrednim skutkiem małżeństwa sakramentalnego jest więź typowo chrześcijańskiej komunii osób, a zasadą i mocą komunii rodzinnej jest miłość. „Pierwszym jej zadaniem jest wierne przeżywanie rzeczywistości komunii w ciągłym działaniu na rzecz rozwijania prawdziwej wspólnoty osób. [...] Miłość pomiędzy mężczyzną i kobietą w małżeństwie i, w formie pochodnej i rozszerzonej, miłość pomiędzy członkami tej samej rodziny - pomiędzy rodzicami i dziećmi, pomiędzy braćmi i siostrami, pomiędzy krewnymi i domownikami - jest ożywiana i podtrzymywana przez wewnętrzny, nieustający

59 Chodzi o „miłość“ w połączeniu z wolnością wzajemnego daru i przyjęcia, realizacją samostanowienia w najwyższym stopniu, właściwym miejscem erotyki w relacji do miłości agape oraz siłą do znoszenia przeciwności (por. F.-J. Nocke, Sakramententheologie. Ein Handbuch, Düsseldorf 1997, s. 270).

Por. H.-J. Höhn, Spüren..., op. cit., s. 119n.

Por. ibidem, s. 121.

Por. A. A. Napiórkowski, Misterium..., op. cit., s. 251-257; M. Jagodziński, Sakramenty w stużbie communio..., op. cit., s. 399n.

Por. A. Skowronek, Matżeństwo i kaptaństwo jako spotęgowanie chrześcijańskiej egzystencji, Włocławek 1996, s. 55-59.

Por. F.-J. Nocke, Sakramententheologie..., op. cit., s. 272n.

Por. H. O. Meuffels, Kommunikative..., op. cit., s. 332n; A. Skowronek, Matżenstwo..., op. cit., s. 63.

Por. J. Salij, Sakrament małżeństwa a sakrament Eucharystii, http://www.kongres-eucharystyczny.mkw.pl/salij.pdf; M. Jagodziński, Sakramenty w stużbie communio..., op. cit., s. 400. 
dynamizm, prowadzący rodzinę do coraz głębszej i mocniejszej komunii, która jest fundamentem i zasadą wspólnoty małżeńskiej i rodzinnej” ${ }^{67}$. Komunia małżeńska ma swoje korzenie w naturalnym uzupełnianiu się mężczyzny i kobiety, jest owocem i znakiem głęboko ludzkiej potrzeby. „Bóg przyjmuje tę potrzebę ludzką, potwierdza ją, oczyszcza i podnosi, prowadząc ją do doskonałości w sakramencie małżeństwa. Duch Święty [...] użycza małżonkom chrześcijańskim daru nowej komunii, komunii miłości, która jest żywym i rzeczywistym obrazem tej najszczególniejszej jedności, która czyni z Kościoła niepodzielne Ciało Mistyczne Chrystusa Pana. Dar Ducha jest życiowym przykazaniem dla małżonków chrześcijańskich, a zarazem podnietą, by z każdym dniem zmierzali ku coraz głębszej więzi pomiędzy sobą na każdym poziomie: na poziomie związku ciał, charakterów, serc, umysłów i dążeń, związku dusz, ukazując w ten sposób Kościołowi i światu nową komunię miłości jako dar łaski Chrystusowej"68. „Rodzina, która jest ze swej natury, i powinna się stawać komunią i wspólnotą osób, znajduje w miłości żywe źródło i stały bodziec do przyjęcia, szanowania i popierania rozwoju każdego z członków, w jego najwyższej godności jako osoby, czyli żywego obrazu Boga. [...] kryterium moralne autentyczności więzów małżeńskich i rodzinnych polega na rozwijaniu godności i powołania poszczególnych osób, które odnajdują swoją pełnię w bezinteresownym darze z siebie samych" ${ }^{69}$. Życie w rodzinie powinno stawać się doświadczeniem komunii: „duchowa komunia rodzin chrześcijańskich, zakorzenionych we wspólnej wierze i nadziei, ożywionych miłością, stanowi wewnętrzną energię, która rodzi i szerzy sprawiedliwość, pojednanie, braterstwo i pokój między ludźmi"70.

Teologia późnośredniowieczna i szkolna redukowała osobową komunię życia, opartą na wielorakiej komunikacji, do tzw. celów małżeństwa. Nowe spojrzenie II Soboru Watykańskiego ${ }^{71}$ ukazuje małżeństwo jako przymierze osobowej wspólnoty życia i miłości we wzajemnym oddaniu się sobie, korelacji i wymianie oraz na tej podstawie rozwija sakramentalne wymiary małżeństwa jako spotkania małżonków z Chrystusem ${ }^{72}$. Chodzi przy tym nie tylko o sam akt jego zawarcia, lecz o całą egzystencję małżeńską ${ }^{73}$. Wspólnota małżeńska

$67 \quad$ Jan Paweł II, adhortacja apostolska Familiaris consortio, 18.

68 Ibidem, 19.

69 Ibidem, 22.

70 Ibidem, 48. Por. M. Jagodziński, Antropologia komunijna, s. 69-73.

71 Por. KK 11; KDK 47-52.

72 Por. KDK 48; Obrzędy sakramentu matżeństwa dopasowane do zwyczajów diecezji polskich, Katowice 1974, s. 1-4.

73 Por. KDK 49. Komentując ten fragment KDK, A. Skowronek (19) dostrzega komunikacyjny wymiar cielesności aktów małżeńskich: „Celem przyjemności połączonej 
to perychoretyczny znak i odbicie perychorezy wewnątrztrynitarnej ${ }^{74}$. Nie pozostał więc ani jeden ślad mentalności patriarchalnej, natomiast uwzględnienie osiągnięć nowożytnego personalizmu spowodowało, że wśród wszystkich egzystencjalnych korelatów miłości małżeńskiej centralne miejsce zajmuje wzajemna wymiana partnerska ${ }^{75}$. Natomiast wyrażenie „Kościół domowy” (KK 11) rozciąga chrystologiczno-eklezjalne rozumienia sakramentalności małżeństwa na posługę wiary całej wspólnoty rodzinnej ${ }^{76}$.

Nowe spojrzenie na sakrament małżeństwa, podkreślające jego jedność i miłość oraz jego cel (por. KK 11; KDK 48), rozwijane jest w dwóch aspektach: komunikacji wiary i komunikacji życia. Zawarcie małzeństwa to spełniane w wierze działanie komunikacyjne mężczyzny i kobiety dokonujące się w czasie eklezjalnej celebracji, w które wchodzi także Chrystus. Wypowiadana zgoda staje się w tym kontekście medium, w którym spotkanie mężczyzny i kobiety ( $z$ inicjatywy Boga) staje się przestrzenią spotkania Boga z człowiekiem. Sakrament oznacza w tym sensie ustanowioną i niekończącą się dynamikę życia, która umożliwia w wierze komunikację z Chrystusem oraz czyni komunikację międzyludzką i międzypłciową symbolem wierności Boga. Natomiast zakłócona komunikacja w małżeństwie staje się symbolem zakłóconego odniesienia do Boga (co wskazuje przy tym na możliwość pokuty i odnowienia wspólnoty z Chrystusem). Implikowane w zgodzie małżeńskiej potencjalne płaszczyzny komunikacji oznaczają z jednej strony uwznioślenie i przemianę społeczno-biologicznych wymiarów partnerstwa w ramach odniesienia ku Bogu, z drugiej zaś realizowanie siebie we wzajemnym współbyciu. Jedność i miłość nie są jednak łatwe do zrealizowania ze względu na zagrożenia, napięcia, wyzwania i zmiany. Wobec wymagań wiary i w obliczu Boga (wymiar transcendentalny) małżonkowie muszą nieustannie w komunikacyjnym dyskursie (wymiar działania) określać swoje odniesienia, żeby ich relacje były wyrazem (wymiar

z rozkoszą jest zatem wyprowadzenie człowieka ponad niego samego, by otworzył się na drugiego i mu się zakomunikował; przyjemność i upojenie to nic innego jak zew do zadzierzgnięcia więzi wspólnotowej”.

74 Por. L. Lies, Sakramententheologie. Eine personale Sicht, Graz - Wien - Köln 1990, s. $148-150$.

75 Por. A. Ganoczy, Einführung in die katholische Sakramentenlehre, Darmstadt 1979, s. 103n; A. Skowronek, Matżeństwo..., op. cit., s. 45-49.

76 Por. T. Schneider, Znaki bliskości Boga. Zarys sakramentologii, Wrocław 1990, s. 321n; H. O. Meuffels, Kommunikative..., op. cit., s. 333; C. S. Bartnik, Dogmatyka katolicka, t. II, s. 788; M. Jagodziński, Sakramenty w stużbie communio..., op. cit., s. 400n. 
estetyczny) ludzkiej i Bożej miłości oraz odpowiadały ich sytuacji życiowej (wymiar historyczny) ${ }^{77}$.

Kościól jest przestrzenią, w której życie Trójjedynego Boga realizuje się w świecie ludzi w tajemnicy poczęcia i miłości, stwarzania, zbawiania i uświęcania, na fundamencie sakramentu małżeństwa. Dlatego małżeństwo jest w pewnym sensie komunijnym fundamentem Kościoła. Nupturienci udzielają go sobie wzajemnie na podstawie wypływającego z chrztu kapłaństwa wspólnego, ale w obecności wyświęconego przedstawiciela Kościoła. Ukazuje to głęboki i komunijny związek horyzontalnego porządku Ludu Bożego z wertykalnym porządkiem hierarchicznej budowy Kościoła ${ }^{78}$. W nawiązaniu do encykliki Piusa XI Casti conubii można dostrzec także komunijne analogie między sakramentami małżeństwa i Eucharystii w postaci trwałości, rozwoju, bycia znakiem nierozdzielnego zjednoczenia Chrystusa z Kościołem. W tych sakramentach realizuje się całościowe zjednoczenie, miłość i szczęście, a także gotowość do wzajemnego oddania oraz odwzorowanie miłości Boga. Małżeństwo jest sakramentem wzajemnego uświęcania się ludzi i aktem kultu, toteż Jan Paweł II wskazał na powiązanie go z Eucharystią, sakramentem nawrócenia i pojednania oraz modlitwą rodzinną ${ }^{79}$. Przez sakrament rodzina staje się małym Kościołem (ecclesiola), „żywą edycją całości Kościoła”: „Miłość małżonków [...] jest jedną z realizacji jednoczącej miłości Kościoła; jest na równi kościelnotwórcza jak i niesiona przez Kościól” (K. Rahner) ${ }^{80}$.

77 Por. H. O. Meuffels, Kommunikative..., op. cit., s. 333-335; M. Jagodziński, Sakramenty w stużbie communio..., op. cit., s. 401n.

Por. J. Auer, Die Sakramente der Kirche, Regensburg 1972, s. 287-289.

„W darze eucharystycznym miłości rodzina chrześcijańska znajduje podstawę i ducha ożywiającego jej «komunię» i jej «posłannictwo»: Chleb eucharystyczny czyni z różnych członków wspólnoty rodzinnej jedno ciało, objawienie szerszej jedności Kościoła i uczestnictwo w niej; uczestnictwo w Ciele «wydanym» i Krwi «przelanej» Chrystusa staje się niewyczerpanym źródłem misyjnego i apostolskiego dynamizmu rodziny chrześcijańskiej” (Jan Paweł II, adhortacja apostolska Familiaris consortio, 57). Sprawowanie sakramentu pokuty powoduje „odkrycie w duchu wiary tego, jak grzech sprzeciwia się nie tylko Przymierzu z Bogiem, ale i przymierzu małżeńskiemu oraz komunii rodzinnej, prowadzi małżonków i wszystkich członków rodziny do spotkania Boga, «bogatego w miłosierdzie», który rozszerzając swą miłość potężniejszą niż grzech, odbudowuje i udoskonala przymierze małżeńskie i komunię rodzinną” (ibidem, 58). Modlitwa rodzinna ,jest modlitwą wspólną męża i żony, rodziców i dzieci. Komunia w modlitwie jest jednocześnie owocem i wymogiem owej komunii, otrzymanej w sakramentach chrztu i małżeństwa" (ibidem, 59).

Por. A. Skowronek, Eucharystia sakrament wielkanocny, Włocławek 1998, s. 185-189; M. Jagodziński, Sakramenty w stużbie communio..., op. cit., s. 402; idem, Antropologia komunijna, op. cit., s. 137-139. 
Słowa kluczowe: sakrament, osoba, sakramentologia personalistyczna, komunikacja, komunia, małżeństwo, rodzina.

\section{Bibliografia:}

1. Auer J., Allgemeine Sakramentenlehre und das Mysterium der Eucharistie, Regensburg ${ }^{2} 1974$.

2. Auer J., Die Sakramente der Kirche, Regensburg 1972.

3. Barth G., Hermeneutyka osoby, Lublin 2013.

4. Bartnik C.S., Dogmatyka katolicka, t. I, Lublin 2000.

5. Bartnik C.S., Dogmatyka katolicka, t. II, Lublin 2003.

6. Benedykt XVI, encyklika Deus caritas est (2005).

7. Caffarra C., Sakramentalna ontologia a nierozerwalność matżenstwa, [w:] Pozostać w prawdzie Chrystusa. Matżeństwo i Komunia w Kościele katolickim, R. Dodaro (red.), Poznań 2015, s. 161-173.

8. Demel S., (K)ein Widerspruch? Unauflöslichkeit der Ehe und Zulassung zu einer Zweitehe, „Herder Korrespondenz" 6 (2014), s. 303-307.

9. Gacka B., Znaczenie osoby w teologii Josepha Ratzingera - Benedykta XVI, Warszawa 2010.

10. Ganoczy A., Einführung in die katholische Sakramentenlehre, Darmstadt 1979.

11. Gerhards A., Stationen der Gottesbegegnung. Zur theologischen Bestimmung der Sakramentenfeiern, [w:] Die Feier der Sakramente in der Gemeinde. Festschrift für Heinrich Rennings, M. Klöckner, W. Glade (red.), Kevelaer 1986, s. 17-30.

12. Gerhartz J.G., Wirklich unauflöslich? Die Ehe in Lehre und Praxis der katholischen Kirche, „Herder Korrespondenz” 8 (2014), s. 389-393.

13. Greshake G., Trójjedyny Bóg. Teologia trynitarna, tł. J. Tyrawa, Wrocław 2009.

14. Höhn H.-J., Spüren. Die ästhetische Kraft der Sakramente, Würzburg 2002.

15. Hryniewicz W., Pascha Chrystusa w dziejach człowieka $i$ Wszechświata. Zarys chrześcijańskiej teologii paschalnej, t. 3, Lublin 1991.

16. Jagodziński M., Antropologia komunijna, Lublin 2015.

17. Jagodziński M., Komunijny wymiar osoby ludzkiej, „Roczniki Teologiczne”, t. LXI, z. 2 (2014), s. 51-63.

18. Jagodziński M., Komunijna wizja sakramentu pokuty i pojednania, [w:] Czy można dzisiaj wzywać do nawrócenia i pokuty? Chrześcijańska odpowiedź wiary, M. Składanowski, T. Syczewski, J. Połowianiuk (red.), Lublin 2015, s. 73-93.

19. Jagodziński M., Sakramenty komunii, „Ruch Biblijny i Liturgiczny” 4 (2009), s. 285-293.

20. Jagodziński M., Sakramenty w stużbie communio. Studium teologiczno-komunikacyjne, Warszawa 2008.

21. Jagodziński M., Trialogiczno-komunijna koncepcja trynitologii, „Studia Diecezji Radomskiej" t. X, Radom 2010/2011, s. 59-72.

22. Jan Paweł II, adhortacja apostolska Familiaris consortio (1981).

23. Jan Paweł II, List do rodzin Gratissimam sane (1994).

24. Jan Paweł II, Mężczyzną i niewiasta stworzyt ich. Odkupienie ciała a sakramentalność matżeństwa, T. Styczeń (red.), Lublin 2008. 
25. Jüngel E, Gott als Geheimnis der Welt, Tübingen 1977.

26. Katechizm Kościoła Katolickiego (1994) (wyd. pol. Poznań 22002).

27. Knauer P., Zur Frage nach der Unauflösligkeit der Ehe. Gibt es wirklich „Privilegium” Paulinum?, „Herder Korrespondenz" 9 (2015), s. 467-469,

28. Kunka S., Teologiczna wizja cielesności czlowieka w nauczaniu Karola Wojtyly - Jana Pawta II, Lublin 2012, s. 36-65.

29. Lachner R., Communio - eine Grundidee des christlichen Glaubens. Ein Beitrag zur Elementarisierung im Fach Dogmatik, [w:] Qualitätsmanagement in der Theologie. Chancen und Grenzen einer Elementarisierung im Lehramtsstudium, R. Lachner, E. Spiegel (red.), Kevelaer 2003, s. 225-251.

30. Lies L., Sakramententheologie. Eine personale Sicht, Graz - Wien - Köln 1990.

31. Lüdicke K., Der neue kirchliche Eheprozess. Evolution oder Revolution?, „Herder Korrespondenz" 10 (2015), s. 509-512.

32. Meuffels H. O., Kommunikative Sakramententheologie, Freiburg - Basel - Wien 1995.

33. Napiórkowski A. A., Misterium communionis. Eklezjalny paradygmat dziejów zbawienia, Kraków 2006.

34. Neuner P., Können wiederverheiratete Geschiedene zum Kommunionempfang zugelassen werden? Nicht immer schwere Sünde, „Herder Korrespondenz“ 6 (2015), s. 299-302.

35. Nocke F.-J., Sakramententheologie. Ein Handbuch, Düsseldorf 1997.

36. Norwid C. K., Człowiek (http://www.poezja.org/utwor-4661.html).

37. Obrzędy sakramentu matżeństwa dopasowane do zwyczajów diecezji polskich, Katowice 1974.

38. Perzyński A., Wtoska antropologia teologiczna. Studium historyczno-dogmatyczne, Łódź 2012.

39. Pius XI, encyklika Casti conubii (1930), http://www.opoka.org.pl/biblioteka/W/ WP/pius_xi/encykliki/casti_connubi_31121930.html.

40. Ratzinger J./Benedikt XVI, „Zur Fräge nach der Unauflöslichkeit der Ehe“. Die beiden Textversionen von Joseph Ratzinger/Benedikt XVI, „Herder Korrespondenz“ 12 (2014), s. 609-612.

41. Resing V., Es ist nicht wie vorher, „Herder Korrespondenz“ 11 (2015), 556n.

42. Resing V., Interview mit Bischof Franz-Josef Bode über die Familiensynode. „Die Fixierung auf das Sexuelle überwinden“, „Herder Korrespondenz" 8 (2015), s. 402-204.

43. Romaniuk K., Sakramentologia biblijna, Warszawa 1994.

44. Rusecki M., Personalizm. II. W teologii, [w:] Encyklopedia katolicka, t. XV, E. Gigilewicz i in. (red), Lublin 2011, 338-341.

45. Salij J., Sakrament malżeństwa a sakrament Eucharystii, http://www.kongres-eucharystyczny.mkw.pl/salij.pdf.

46. Sautermeister J., Zum Prinzip der Gradualität im Kontekst der Familiensynode. Das Prozesschafte in der Lebensführung, „Herder Korrespondenz“ 5 (2015), 229-233.

47. Schaeffler R., P. Hünermann, Ankunft Gottes und Handeln des Menschen. Thesen über Kult und Sakrament, Freiburg - Basel - Wien 1977.

48. Schilson A., Katholische Sakramententheologie auf neuen Wegen? Bemerkungen zu einer Neuerscheinungen, „Herder Korrespondenz“ 33 (1979), s. 571-576. 
49. Schmälzle U.F., Es geht um Heilung. Für eine alternative Pastoral zum Umgang mit wiederverheirateten Geschiedenen, „Herder Korrespondenz" 7 (2014), s. 348-353.

50. Schneider T., Znaki bliskości Boga. Zarys sakramentologii, Wrocław 1990.

51. Schockenhoff E., Die zwei Seiten eines Texte. Die Wortmeldung des emeritierenden Papstes zur Debatte um wiederverheiratete Geschiedene, „Herder Korrespondenz“ 12 (2014), s. 605-609.

52. Schockenhoff E., Liebe auf Abwegen? Zum Verhältnis von Sexualität und Liebe in intimen Beziehungen, „Theologisch-praktische Quartalschrift“ 4 (2015), s. 339-346.

53. Scola A., Osoba ludzka. Antropologia teologiczna, Poznań 2005.

54. Skowronek A., Eucharystia sakrament wielkanocny, Włocławek 1998.

55. Skowronek A., Matżeństwo i kapłaństwo jako spotęgowanie chrześcijańskiej egzystencji, Włocławek 1996.

56. Sobór Watykański II, konstytucja dogmatyczna o Kościele Lumen gentium (1964).

57. Sobór Watykański II, konstytucja duszpasterska o Kościele w świecie współczesnym Gaudium et spes (1965).

58. Splett J., Ehe als Bund. Zur Diskussion um den Status Weiderverheirateten, „Herder Korrespondenz" 3 (2015), s. 144-149.

59. Szymik J., Religio vera. Rzeczywistość chrześcijaństwa-chrześcijański wymiar rzeczywistości wedtug Josepha Ratzingera/Benedykta XVI, „Teologia w Polsce” 7 (2013) nr 2, s. 3-22.

60. Valverde C., Antropologia filozoficzna, Poznań 1998.

61. Werlen M., Die katholische Kirche und die Herausforderung des Zeitgeistes. Angesichts der Traditionen die Tradition nicht vergessen, „Herder Korrespondenz“ 9 (2015), s. 463-466.

62. Zizioulas J.D., Human Capacity and Human Incapacity: A Theological Exploration of Personhood, „Scottish Journal of Theology” 28 (1975), s. 401-448.

63. Zulehner P.M., Differenzierung ist nötig. Was Katholiken über die Ehe denken?, „Herder Korrespondenz" 3 (2014), s. 129-134 